\title{
The Development Of Anti Miskim Software To Reduce Misconception Of Students On Buffer Solution Matter Through Conceptual Change Text Strategy
}

\author{
Siti Agustiyaningsih \\ Chemistry Department \\ Universitas Negeri Surabaya \\ Surabaya, Indonesia
}

\author{
Sukarmin \\ Chemistry Department \\ Universitas Negeri Surabaya \\ Surabaya, Indonesia \\ sukarmin@unesa.ac.id
}

\author{
Utiya Azizah \\ Chemistry Department \\ Universitas Negeri Surabaya \\ Surabaya, Indonesia
}

\begin{abstract}
The purpose of this study is to determine the feasibility of anti-miskim software with the conceptual change text strategy as a learning media to reduce misconceptions in buffer solution material. Feasibility of the software in terms of criteria validity, practicality, and effectiveness. This type of research applies Borg \& Gall's research and development methods, but in this study only carried out until the fifth stage which includes (1)research and information collecting, (2)planning, (3) developing preliminary form of product, (4)preliminary field testing, \& (5)playing product revision. This study was conducted on 12 students with the highest level of misconception in the buffer solution material in the class. The results showed that software is feasibly used to reduce students' misconceptions in the buffer solution. This is indicated by the results of content and construct validation got percentage $84.03 \%$ and $82.47 \%$ and classified as very valid criteria. Practically categorized based on the percentage of student response results of $91.67 \%$ and student activities of $96.67 \%$ which categorized as very practical. Effectiveness in terms of the percentage shifting from misconceptions to knowing concepts is $82.59 \%$ which is categorized as very effective and it can be concluded that anti miskim software is proper to use.
\end{abstract}

Keywords-software, conceptual change text, misconception, buffer

\section{INTRODUCTION}

Education plays a role in preparing humans to have skills so they are ready to contribute to world civilization. The government has tried to make changes in the education process with the hope of being able to improve it better by improving the education curriculum from the 2006 curriculum to the curriculum 2013. The subjects listed in the structure of the senior high school curriculum are chemistry subjects.

Learning chemistry at the senior high school level learns about everything related to substances both composition, structure, properties, changes to energetics. In chemistry learning, one of the important things that cannot be separated is chemistry as a product. Chemistry as a product includes facts, concepts, principles, laws, and theories found by experts or scientists [1]. Chemistry has interrelated relationships regarding the understanding of a concept, which understanding will influence the understanding of the next concept. So that chemical learning is carried out needs to be done an emphasis on the concepts taught to students, because it is expected that there will be no mistakes in understanding the concepts taught.

Understanding concepts that are not appropriate will lead to misconceptions in students. Errors in understanding concepts will result in learning objectives to be achieved by students to be disrupted and not even be achieved properly. Based on Kirbulut \& Geban's research state that a lot of research's result in the science education field report that misconception can affect the learning and understanding process [2]. Ibrahim states that misconception is an understanding held by students of a concept that is not in accordance with scientific concepts that are agreed upon and deemed right by experts [3]. Misconception that are resistant to change, persistent, and embedded in the cognitive of the individual will be difficult to overcome even with instructions designed to overcome those problems [4]. Misconceptions experienced by students can be detected by using the three-tier test method which is a diagnostic test consisting of three levels of questions which include one tier in the form of multiple choice questions, second tier in the form of selected answer choices, and three-tier in the form of affirmation questions about beliefs from the first and second levels. The test results of understanding the concepts of the students in the analysis used descriptive analysis of conceptual concepts, and grouped students into conceptual concepts, not knowing concepts, and misconceptions (MK) [5]. Distribution of the level of understanding of students to an important concept to be clearly known, so that it can help the implementation of the learning objectives carried out so that it can be achieved properly.

Chemical material which often experiences misconceptions, one of which is in the subject matter of the buffer solution. Buffer solutions based on material characteristics are conceptual. So to understand these material students must understand the concept well and know the inter-conceptual relationship and be able to apply the concept in solving problems. This is in line with the results of Nurhidayatullah \& Prodjosantoso research showing that there were $47 \%$ of the buffer solution material, $37 \%$ understood the concept, and $16 \%$ did not understand the concept [6]. The distribution of the most misconceptions 
occurred in 3 concepts of buffer solution namely $43.37 \%$ in the concept of the definition of buffer solution, $31.27 \%$ in the concept of calculating the $\mathrm{pH}$ of the buffer solution, and $64.08 \%$ in the concept of the working principle of a buffer solution by adding a little acid or base to the solution buffer [6].

Pre-research data on the three concepts of buffer solution are the concept of buffer solution, the working principle concept of buffer solution with the addition of acids, bases or water and the concept of calculating the buffer solution $\mathrm{pH}$ that has been done in three schools, namely class XII Science of Senior High School 1 Krembung with the amount 30 students, distribution of misconceptions of the concept of buffer solution as much as $68 \%$, the working principle of the buffer solution with the addition of a little acid, base, or water by $70 \%$, and the concept of calculating the $\mathrm{pH}$ of the buffer solution as $62 \%$. Class XII Science of Senior High School 1 Kamal with a total of 32 students, the distribution of misconceptions of the concept of buffer solution as much as $65 \%$, the working principle concept of buffer solution with $76 \%$ addition of acid, base, or water, and the concept of calculating the buffer solution $\mathrm{pH}$ of $72 \%$. Class XII Science of Senior High School Cerme with a total of 20 students, distribution of misconceptions of the concept of buffer solution as much as $58 \%$, the working principle concept of buffer solutions with the addition of a little acid, base, or water as much as $60 \%$, and the concept of calculating the buffer solution $\mathrm{pH}$ as much as $58 \%$. So, need concrete solutions that must be done to solve the problem of misconception.

The problem of misconception in the material of buffer solutions experienced by students becomes very important to overcome so that there is a shift in misconceptions. One way that can be used to correct misconceptions is to use a conceptual change strategy that requires students not to be easily satisfied with existing conceptions but they are able to be motivated in finding new concepts that are easier to understand, make sense, and provide a benefit more so, before conceptual restructuring will occur [3]. Thus, the conceptual change strategy is considered capable of reducing students 'misconceptions caused by students' cognition such as preconceptions / initial knowledge possessed by students. This is supported by the results of research by Nikmah \& Suyono which states that effective conceptual change learning strategies in remediating student misconceptions are evidenced by the shift in conceptions of students from misconception 2 and misconception 3 to change into conceptual understanding [7]. Another study that supports the conceptual change strategy that is effective in remediating misconceptions is the research conducted by Sari \& Nasrudin which states that the assessment of the implementation of the conceptual change learning strategy in meetings I, II, and III is categorized very well, ie amounting to $95.24 \%$; $95.00 \%$; and $93.00 \%$, a shift in students' misconceptions showed that most of them were directed towards knowing concepts [8]. Aydin states that the kind of conceptual change that has been applied and is capable of remediating misconceptions is one of them is conceptual change text (CCT) [9]. Ozmen's research states that conceptual change is successful in remediating alternative conceptions of students in chemical equilibrium material rather than traditional instruction, this is evidenced by the posttest score compared with the t-test there is a statistically significant difference between the experimental groups $(\mathrm{M}=14.58, \mathrm{SD}=4.67)$ and the control group $(\mathrm{M}=11.18, \mathrm{SD}=3.52)$ which states the effectiveness of conceptual change text [10]. Aslan \& Demircioglu state that conceptual change text is a method for changing the conceptual through restructuring and assimilation processes [11]. Conceptual change text can help the learning process independently and improve student's reading skills, so the learning process at the class is more effective with the initial knowledge of students [11]

The buffer solution material consists of the concept of macroscopic, microscopic and symbolic levels. The use of interactive multimedia can be used as a medium that can support the remediation process of misconceptions in buffer solution material. This is because interactive multimedia combines animation, images, text, audio, and video, so that the concept of buffer solution is expected to be easily understood and remembered by students. Fitria's research, Priatmoko, \& Kasmui states that the use of interactive multimedia can minimize students' misconceptions in the subject matter of buffer solutions indicated by the average experience of misconception in the experimental class lower than the control class, increasing cognitive learning outcomes in the experimental class more compared to the control class, the average answer classified as misconception in the experimental class was lower than the control class [12].

In line with the description above, it becomes important to develop learning media in order to reduce student misconceptions so as to be able to support the learning process to achieve learning goals, so that researchers want to develop a study entitled "Anti-Miskim Software Development to Reduce Student Misconceptions In the Main Material of Buffer Solution through Conceptual Change Text Strategy "

\section{METHODS}

The development research method used in preparing this software is the Research \& Development (R\&D) based on Borg \& Gall 1983. There are ten steps in this method, however in this research limited until the fifth steps they are: (1) research and information collecting, (2) planning, (3) developing preliminary form of product, (4) preliminary field testing, (5) main product revision [13].

The research subjects used in this research were 12 students of class XII IPA SMAN 1 Krembung Sidoarjo. Students who participate in limited trial stage are students who have obtained buffer solution material and students who detected the highest misconceptions. Analysis of the data used in this study include validation, students activity observation, questionnaire students responses, and the test results of students 'misconception shifts.

Validation data were obtained after the validator consisting of 2 chemistry lecturers and 1 chemistry teacher gave a quantitative assessment using scores. The percentage of data used the Likert rating scale calculation in Table 1 


\section{A. Validity of Software}

Validation aims to determine the assessment from chemistry lectures and chemistry teacher on the feasibility of software that developed. There were two validity aspect including content validity and construct validity.

From the results of the assessment that has been carried out by three validators such as two chemistry lectures and one chemistry teacher obtained the percentage shown in Table VIII is the result of content validity of software and table IX is the result of construct validity of software.

TABLE VIII. DATA OF CONTENT VALIDITY RESULT

\begin{tabular}{llll}
\hline Nu & \multicolumn{1}{c}{ Criteria } & Percentage & Category \\
\hline 1 & The truth of the material & $81.25 \%$ & Very Valid \\
& $\begin{array}{l}\text { The suitability of the questions } \\
\text { in the software with purpose }\end{array}$ & $83.33 \%$ & Very Valid \\
3 & $\begin{array}{l}\text { The suitability of the video in } \\
\text { the software }\end{array}$ & $87.50 \%$ & Very Valid \\
Average & $84,03 \%$ & Very Valid \\
\hline
\end{tabular}

In content validity, there are three assessment criteria which include, the truth of the material in the software, the suitability of the software question with the purpose, and the suitability of the video in the software. The three assessment criteria each obtained a percentage of $81.25 \%, 83.33 \%$, and $87,5 \%$, with an average of $84.03 \%$, so that in accordance with the feasibility criteria in terms validity of software that developed got a percentage of $\geq 61$ $\%$ that can be categorized as very valid category [10]. This is because in the preliminary study phase a literature study was conducted in which the researchers analyzed basic competency and buffer solution materials in the 2013 curriculum and looked for literature to support the material substance in software content in the conceptual change text stages and the pretest and posttest questions presented to find out the results of the shift in students' misconceptions. As the criteria for selecting a good learning media, one of them is the suitability of media content with the objectives of learning to be achieved [16]. Anti miskim software is a software program created with the PHP programming language system. The software that developed, will be used as a media to remediate students' misconceptions on the subject matter of the buffer solution.

Software validity is also reviewed from construct validity. Construct validity relates to linguistic criteria, presentation criteria and appearance suitability criteria. Based on the results of three validators, the software construct validity is given in table IX.
TABLE IX. RESULTS OF CONSTRUCT VALIDITY DATA

\begin{tabular}{clcc}
\hline Nu & \multicolumn{1}{c}{ Criteria } & Percentage & Category \\
\hline 1 & $\begin{array}{l}\text { The software requirements } \\
\text { to reduce misconceptions }\end{array}$ & $85.42 \%$ & Very Valid \\
2 & $\begin{array}{l}\text { The characteristics of the } \\
\text { video in the software }\end{array}$ & $80.56 \%$ & Very Valid \\
3 & $\begin{array}{l}\text { The feasibility of } \\
\text { presenting software } \\
\text { Language and display of } \\
\text { software } \\
\text { Average }\end{array}$ & $83.33 \%$ & Very Valid \\
$\quad 80.55 \%$ & Very Valid \\
& $82.47 \%$ & Very Valid \\
\hline
\end{tabular}

Construct validity criteria consist of four assessment criteria. The first criterion got a percentage of $85.42 \%$ is the software requirement as a media that used to remediate misconceptions, these criteria are important for the process of detecting and remediating student's misconceptions because in these criteria there are several aspects, the first aspect is the item presented is able to show conception of students. Through the three-tier diagnostic test method, which is more efficient, it is used because there are levels of interrelated questions so that reasoning can be done on the level of understanding of students' concepts [5]. The second aspect of the first criterion is that there are components that can lead to a process of cognitive conflict and components that can create a situation to change the wrong conception to be true and a component that can reconstruct the concept correctly. This is in accordance with Ibrahim's statement in his book which states that the restructuring of concepts and assimilation is done when students experience conceptual conflict [3]. The second criterion is the characteristics of the video in the software must use good and correct language, communicative and not contain ethnicity, religion, race, and inter-group relations elements to obtain a percentage of $80.56 \%$. The third criterion is related to the feasibility of presenting the software, starting from the appearance, feasibility and ease of use obtaining a percentage of $83.33 \%$. The fourth criterion related to language and appearance in software must be correct, communicative, and not cause many interpretations to obtain a percentage of $80.55 \%$. These results are in accordance with the requirements for the selection of good learning media, some of which are varied and innovative and in accordance with the characteristics of the learning material [16]. So that based on the results of the assessment of the average percentage of content validity and constructs each obtained a percentage of $84.03 \%$ and $82.47 \%$, and had fulfilled the criteria for software feasibility in terms of validity assessments of $\geq 61 \%$ with very valid categories [14 ]

\section{B. Practicality of Software}

The practicality of the software in terms of the observations of the activities of students during the trial was limited and the results of the questionnaire responses of the students. The following in Table X. presented the results of observations of students. 
TABLE X. OBSERVATION RESULT OF STUDENT ACTIVITY

\begin{tabular}{|c|c|c|c|}
\hline $\mathrm{Nu}$ & Activity & Percentage & Category \\
\hline 1 & $\begin{array}{l}\text { Log in software properly (not } \\
\text { asking questions) }\end{array}$ & $100 \%$ & Very practical \\
\hline 2 & $\begin{array}{l}\text { Reading the instructions of } \\
\text { software }\end{array}$ & $100 \%$ & Very practical \\
\hline 3 & $\begin{array}{l}\text { Doing pretest independently } \\
\text { (do not ask other students) }\end{array}$ & $100 \%$ & Very practical \\
\hline 4 & $\begin{array}{l}\text { Reading conceptual change } \\
\text { text stage } 1\end{array}$ & $100 \%$ & Very practical \\
\hline 5 & $\begin{array}{l}\text { Reading conceptual change } \\
\text { text stage } 2\end{array}$ & $100 \%$ & Very practical \\
\hline 6 & $\begin{array}{l}\text { Looking closely at the video } \\
\text { in conceptual change text } \\
\text { stage } 2 \text { (not skip / skip } \\
\text { videos) }\end{array}$ & $100 \%$ & Very practical \\
\hline 7 & $\begin{array}{l}\text { Reading the material on } \\
\text { conceptual change text stage } \\
3 \text { (not skip / skip videos) }\end{array}$ & $97,22 \%$ & Very practical \\
\hline 8 & $\begin{array}{l}\text { Looking at video material } \\
\text { carefully in conceptual } \\
\text { change text stage } 3 \text { (not skip } \\
\text { / skip videos) }\end{array}$ & $97,22 \%$ & Very practical \\
\hline 9 & $\begin{array}{l}\text { Answering the questions in } \\
\text { conceptual change text stage } \\
3\end{array}$ & $94,44 \%$ & Very practical \\
\hline 10 & $\begin{array}{l}\text { Answering the problem in } \\
\text { conceptual change text stage } \\
4\end{array}$ & $100 \%$ & Very practical \\
\hline 11 & $\begin{array}{l}\text { Doing posttest independently } \\
\text { (do not ask other students) }\end{array}$ & $100 \%$ & Very practical \\
\hline 12 & $\begin{array}{l}\text { Operatinh the buttons of } \\
\text { software properly (not asking } \\
\text { questions) }\end{array}$ & $86,11 \%$ & Very practical \\
\hline 13 & $\begin{array}{l}\text { Students do not leave the } \\
\text { room during the trial } \\
\text { (without reason) }\end{array}$ & $94.44 \%$ & Very practical \\
\hline 14 & $\begin{array}{l}\text { Understanding the language } \\
\text { used in the software (not } \\
\text { asking questions) }\end{array}$ & $88,89 \%$ & Very practical \\
\hline 15 & $\begin{array}{l}\text { Students are motivated to } \\
\text { learn (this can be seen from } \\
\text { the wav students focus on) }\end{array}$ & $91,67 \%$ & Very practical \\
\hline & Average & $96,67 \%$ & Very practical \\
\hline
\end{tabular}

The aspects observed in the observation sheet are the activities of students in accordance with the stages in the use of software and conceptual change text to detect and remediate the students' misconceptions. Based on the results of the average percentage in table 10 it appears that students are enthusiastic and motivated in carrying out activities with an average percentage of $96.67 \%$, which based on the feasibility assessment criteria in terms of practicality that is $\geq 61 \%$ can be categorized as very valid [14]. The stages of software use are also in line with Posner, Strike, Hewson, \& Gertzog which states that there are four steps in problemoriented learning, namely: 1)dissatisfaction, 2)clarity, 3)plausibility, and 4)fertility [17]. In addition, from the results of the practicality assessment on the observations of the activities of students, it can be said to be in accordance with the criteria of a good learning media that is able to motivate students and ease of use in accordance with the conditions of students [16].

The feasibility assessment in terms of practicality is also viewed from the results of the students' response questionnaire which consists of several criteria, namely knowing the practicality of each step in the conceptual change text, software can increase learners' curiosity, language clarity, ease of use of software and learners' motivation to learn more many. The results of the student questionnaire responses are presented in Table XI.

TABLE XI. QUESTIONNAIRE RESPONSES OF STUDENTS RESULT

\begin{tabular}{|c|c|c|c|}
\hline Nu. & Criteria & Percentage & Category \\
\hline 1 & $\begin{array}{l}\text { Criteria of each step of } \\
\text { conceptual change text, }\end{array}$ & $98,83 \%$ & Very practica \\
\hline 2 & $\begin{array}{l}\text { Software can rise the } \\
\text { curiosity of students, }\end{array}$ & $91,67 \%$ & Very practica \\
\hline 3 & Language, & $91,67 \%$ & Very practica \\
\hline 4 & $\begin{array}{l}\text { Ease of use of software, } \\
\text { and }\end{array}$ & $87,5 \%$ & Very practica \\
\hline 5 & $\begin{array}{l}\text { Students motivation to } \\
\text { study more }\end{array}$ & $91,67 \%$ & Very practica \\
\hline & Average & $91,67 \%$ & Very practica \\
\hline
\end{tabular}

The first criterion is the practicality in each stage of conceptual change text consisting of aspects of ease of language understanding, clarity of statement, material compatibility at each stage contained in the conceptual change text software obtained a percentage of $95.83 \%$.

The criteria for both software can attract students' curiosity, including attractive and not monotonous appearance, and whether students prefer to learn to use software or not get a percentage of $91.67 \%$. Learning media that are used well are those that are in accordance with the conditions of students and are able to motivate students [14]. In this software illustration, the video or image used is expected to motivate students so that students can be enthusiastic and have an interest in learning the material of gossip solution in conceptual change text that has been presented in software so that it is expected to remedy the misconceptions that occur.

The third criterion of language clarity consisted of aspects of the language used in the software, questions and material in the conceptual change text contained in the software obtained a percentage of $91.67 \%$. The criteria for ease of use of the software include aspects of the user manual presented in the software and the overall use of the software to obtain a percentage of $87.5 \%$. These results are in accordance with the conditions for selecting a good learning media are media that can be used easily by teachers and students [14]. The fifth criterion is related to student motivation including whether this software is able to make students interested in learning chemistry and can increase their learning enthusiasm. This is because learning media that are used well are those that are in accordance with the conditions of the students and are able to motivate the participants in learning [14].

Based on the results of the assessment of observations of student activities and response questionnaires in the software developed, both of them got a percentage of $96.67 \%$ and $91.67 \%$, respectively, and fulfilled the criteria for evaluating software feasibility in terms of practical assessment of $\geq 61 \%$ with categories that very practical [14].

\section{Effectiveness of Software}

The effectiveness of anti-miskim software is obtained from the results of the shift in the concept of students from misconceptions to knowing concepts. The following in 
Figure 1. is a graph of the shift in concept of students from Misconception to Knowing concept for each concept.

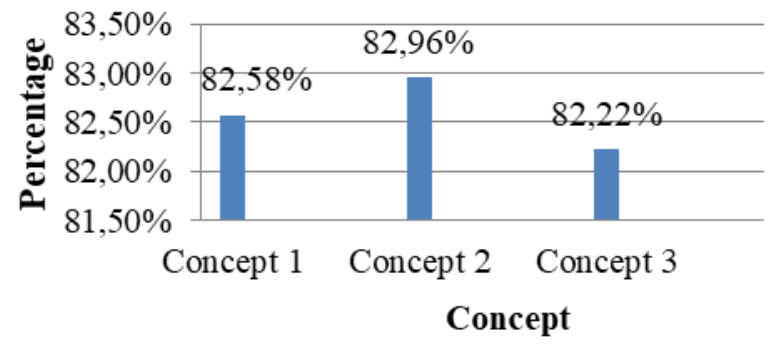

Fig. 1. Misconception Shifting Misconception to Knowing Concept

Note :

Concept $1=$ Buffer Solution

Concept $2=$ Working Principle of Buffer Solution

Concept 3 = Calculation of $\mathrm{pH}$ of Buffer Solution

Based on the assessment criteria for software effectiveness, states that the software developed by researchers can be said to be effective if the assessment of the concept shift from misconception to know the concept meets the percentage criteria $\geq 61 \%$. The results of the concept shift of students from misconception to knowing concept on the buffer solution concept is $82.58 \%$, for the second concept, the concept of the working principle of buffer solution has a percentage of $82.96 \%$, and the third concept is the concept of calculating the $\mathrm{pH}$ of buffer solution the percentage is $82.22 \%$. Based on the percentage, the lowest percentage value can be seen in the third concept, this means that the smallest shift in the concept of students is the concept of calculating the $\mathrm{pH}$ of the buffer solution. Based on the results of software output states that from the posttest questions presented with the three-tier test method, the answers of the students are correct but the reasons for the answers and the level of confidence are still wrong and there are still students who are unsure of their answers. This means that the understanding of the formula for calculating the $\mathrm{pH}$ of a buffer solution does not have a problem, but some students who obtain a negative shift indicate they still do not understand correctly about the reason why the calculation formula is arranged in such a way.

The percentage of the three concepts if averaged then the percentage is $82.59 \%$ and based on the software feasibility assessment criteria this percentage is included in the range of $81 \%-100 \%$ which can be categorized as very effective [14]. These results are also in line with the results of Suprianto \& Sukarmin's research stating that the use of software media can mediate misconceptions that occur in students [18], besides the Ozmen study also states that there are significant differences in t-test results between experimental and control groups [10], this means that the application of the conceptual change text strategy can remediate the misconceptions experienced by students. So that the overall results show that the anti-miskim software developed is classified as very effective in reducing students' misconceptions in the subject matter of the buffer solution.

\section{CONCLUSION AND SUGGESTION}

\section{A. Conclusion}

Based on data from the results of validation by two chemistry lecturers and one chemistry teacher, student response questionnaire, observation of student activities, and students' misconception shifts that have been analyzed, it can be concluded that anti miskim software that is developed properly is used to reduce student misconceptions, with details as follows.

1. Anti miskim software developed has been declared valid which is shown from the acquisition of the average percentage of content validity of $84.03 \%$ with very valid criteria and construct validity of $82.47 \%$ with very valid criteria.

2. Anti miskim software that was developed has been declared practical which is shown from the results of student questionnaire responses and student activities with an average percentage of $91.67 \%$ with very practical criteria and $96.67 \%$ with very practical criteria.

3. Anti miskim software that was developed has been declared effective as shown by the acquisition of the results of the misconception shift of students to know the concept with an overall percentage of $82.59 \%$ with very effective criteria.

\section{B. Suggestion}

Based on the research that has been done, it was found that anti-miskim software has met the software eligibility criteria, which are valid, practical, and effective. Some of the suggestions given for improvement in future research are as follows:

1. The development of anti-miskim software on the subject matter of the buffer solution is still carried out until the revision phase of the results of a limited field trial that only focuses on formulating what things need to be improved, so that implementation is needed regarding these improvements in further research.

2. When the field trial is limited, it is better to make a detailed schedule in advance regarding the activities and the estimated time needed which is also adjusted to the time given and permitted by the school, so that when on the field according to the schedule and can utilize the time provided by the school as well as possible.

3. The results of anti-miskim software development research have received positive responses, so it needs to be developed in other chemical materials.

\section{ACKNOWLEDGMENT}

The preparation of anti miskim software cannot be separated from the help of various parties, therefore the authors would like to express their gratitude to:

1. Ir. Siti Tjahjani, M.Kes., as Academic Advisor who has given valuable guidance and advice while studying in the Department of Chemistry. 
2. Prof. Dr. Madlazim, M.Si., as Dean of FMIPA, State University of Surabaya.

3. All parties who have helped resolve this thesis.

\section{REFERENCES}

[1] BSNP, B. S. (2006). Standar Isi Satuan Pendidikan Dasar dan Menengah. Jakarta: BSNP (Badan Standar Nasional Pendidikan).

[2] Kirbulut, Z. D., \& Geban, O. (2014). Using Three-Tier Diagnostic Test to Asses Students' Misconceptions of States of Matter. Eurasia Journal of Mathematics Science and Technology Education, 10(5), 509-521

[3] Ibrahim, M. (2012). Seri Pembelajaran Inovatif "Konsep, Miskonsepsi, dan Cara Pembelajarannya". Surabaya: Unesa University Press.

[4] Fisher, K. M. (1985). A Misconception In Biology Amino Acids and Translation. Journal of Research In Science Teaching, 22(1), 53-62.

[5] Arslan, H. O., Cigdemoglu, C., \& Moseley, C. (2012). A Three-Tier Diagnostic Test to Assess Pre-Service Teachers' Misconceptions about Global Warming,Greenhouse Effect, Ozone Laye rDepletion, and Acid Rain. International Journal of Science Education, 34(11), 1667-1686.

[6] Nurhidayatullah, N., \& Prodjosantoso. (2018). Miskonsepsi Materi Larutan Penyangga . Jurnal Inovasi Pendidikan IPA, 4(1), 85-89.

[7] Nikmah, K., \& Suyono. (2015). Penerapan Strategi Pembelajaran Conceptual Change Untuk Meremediasi Miskonsepsi Pada Konsep Asam-Basa Siswa Kelas Xii Ipa Sman 1 Waru Sidoarjo. UNESA Journal of Chemical Education, 4(3), 541-550.

[8] Sari, M. W., \& Nasrudin, H. (2015). Penerapan Model Pembelajaran Conceptual Change Untuk Mereduksi Miskonsepsi Siswa Pada Materi
Ikatan Kimia Kelas X Sma Negeri 4 Sidoarjo. UNESA Journal of Chemical Education, 4(2), 315-324.

[9] Redhana, I., Sudria, I., Hidayat, I., \& Merta, L. (2017). Identification Of Chemistry Learning Problems Viewed From Conceptual Change Model . Jurnal Pendidikan IPA Indonesia, 6(2) 356-364.

[10] Ozmen, H. (2007). The Effectiveness of Conceptual Change Texts in Remediating High School Students' Alternative Conceptions Concerning Chemical Equilibrium. Education Research Institute, $8(3), 413-425$.

[11] Aslan, A., \& Demircioglu, G. (2014). The Effect of Video-Assisted Cocneptual Change Texts on 12th Grade Students' Alternativ Conceptions : The Gas Concept. Procedia Social and Behavioral Sciences, 116, 3115-3119

[12] Fitria, Priatmoko, S., \& Kasmui. (2016). Penggunaan Multimedia Interaktif Dalam Meminimalisasi Miskonsepsi Siswa Pada Materi Pokok Larutan Penyangga. Jurnal Inovasi Pendidikan Kimia, 10(1), 1641-1650.

[13] Borg, W. R., \& Gall, M. D. (1983). Educational Research An Introduction. New York: Longman.

[14] Riduwan. (2015). Skala Pengukuran Variabel-variabel Penelitian. Bandung: Alfabeta.

[15] Plomp, T., \& Nieveen, N. (2013). Educational Design Research. Enschade Netherland: SLO, Netherland Institute for Curriculum Development.

[16] Darmadi.(2017).Pengembangan Model Metode Pembelajaran dalam Dinamika Belajar Siswa.Yogyakarta : Deepublish

[17] Posner, G. J., Strike, K. A., Hewson, P. W., \& Gertzog, W. A. (1982). Accomodation of a Scientific Conception:Toward a Theory of Conceptual Change. Science Education.

[18] Suprianto, \& Sukarmin. (2016). Pengembangan Software Pengukur Tingkat Konflik Kognitif. Unesa Journal of Chemical Education, 5(2), 359-366 